\title{
The CEO Characteristics Factors Toward Tax Aggressiveness of Family Companies in Indonesia
}

\author{
Rachmawati Meita Oktaviani $^{1,}{ }^{*}$, Kukrit Wicaksono ${ }^{2}$, Sunarto Sunarto ${ }^{3}$, and Ceacilia \\ Srimindarti ${ }^{4}$ \\ 1,2,3,4 Department of Accounting, Faculty of Economics and Bussiness, University of Stikubank, \\ Semarang, Indonesia \\ Email address: \\ meitarachma@edu.unisbank.ac.id
}

\begin{abstract}
This study examines the relationship between the characteristics of the CEO that has an effect toward tax aggressiveness of family companies in Indonesia. Purposive sampling is done to get samples, there are 70 samples with 280 total observations. Estimation model test is used in determining the proper estimation model regression, after all, REM is chosen as the estimation model. The study results that CEO tenure and risk preferences has an effect toward tax aggressiveness of family companies while educational background of CEO has no significant effect toward tax aggressiveness. More than $95 \%$ of companies in Indonesia are family companies. Government should do any actions to maximize state tax revenue. This study adds CEO risk preference as the development of prior research in order to examine another variable that might has an effect toward tax aggressiveness of family companies in Indonesia.
\end{abstract}

Keywords: CEO educational background, tenure, risk preferences, tax aggressiveness.

\begin{abstract}
Abstrak: Penelitian ini menguji hubungan antara karakteristik CEO yang berpengaruh terhadap agresivitas pajak perusahaan keluarga di Indonesia. Pengambilan sampel dilakukan secara purposive sampling untuk mendapatkan sampel sebanyak 70 sampel dengan total observasi 280 orang. Uji model estimasi digunakan dalam menentukan model estimasi regresi yang tepat, karena REM dipilih sebagai model estimasi. Hasil penelitian bahwa masa jabatan CEO dan preferensi risiko berpengaruh terhadap agresivitas pajak perusahaan keluarga sedangkan latar belakang pendidikan CEO tidak berpengaruh signifikan terhadap agresivitas pajak. Lebih dari 95\% perusahaan di Indonesia adalah perusahaan keluarga. Pemerintah harus melakukan berbagai tindakan untuk memaksimalkan penerimaan pajak negara. Penelitian ini menambahkan preferensi risiko CEO sebagai pengembangan dari penelitian sebelumnya untuk menguji variabel lain yang mungkin berpengaruh terhadap agresivitas pajak perusahaan keluarga di Indonesia.
\end{abstract}

Kata Kunci: latar belakang CEO, masa kerja, preferensi risiko, tax aggressiveness.

\section{INTRODUCTION}

Basically a company was founded to gain profit. Shareholders are the owners of shares in a company which means investing in the company so they expect a return on the capital that has been given. Therefore, the company will compete with other competitors for profit 
and based on (Porter, 1980), explained that a company need a competitive advantage to win the competition. The company would make any efforts to create the competitive advantage, one of those efforts is minimizing expenses to achieve cost leadership (Porter, 1980). There are some cathegories of expense in financial statement. They are operational expense, nonoperational expense, and tax expense. The profits earned by the company is in contrast to taxes which are a source of state revenue. The state will try to maximize its tax collection to finance the country's operational activities. Based on information of the 2019 State Budget (APBN) compiled by the Directorate of State Budget Preparation and the Directorate General of Budget, taxes contribute as much as $82.5 \%$ of total domestic revenue. This shows that government would make any efforts to collect taxes because it has a main role in state revenue.

Company could be classified as non-family firm or family firm. Based on (Martinez et al., 2014), the family firm is more aggressive than non-family firm toward taxes. Meanwhile, a survey did by $(\mathrm{PwC}, 2014)$, revealed that $95 \%$ businesses in Indonesia are family firms. Thus, the government must be able to accommodate the factors that affect the aggressiveness of family companies towards taxes in order to maximize their tax collections. The intensity of taxes minimization done by company called as tax aggressiveness. (Frank et al., 2009), stated that the action taken by the company and showing aggressiveness towards taxes is tax planning made through tax avoidance (legal way) and tax evasion (illegal way).

The power to be more or less aggressive toward tax is owned by the decision makers. In the Upper Echelons Theory presented by (Hambrick et al., 1984), the power holder in making a policy is the top level management. Tax planning can be done by more aggressively when the members of management are affiliated and have the same goals which is to pursue higher profits. Especially for the family companies, the problem among the boards about tax aggressiveness would be less because at least one of them is affiliated with the controller or founder or acquirer as a family. (Hambrick et al., 1984), stated that the characteristics possessed by top level management affect them in making a policy. So that the government must be able to accommodate the characteristics of the CEO as a top level management in a company that has the power to regulate its tax expenses through tax planning.

A person will go through a selection process to be elected as a company CEO and the most basic selection is the educational background. Education has an important role for someone to be recruited as CEO (Bhagat et al., 2012). (Bhagat et al., 2012), stated that higher education has a bigger opportunity to be placed in the CEO position. Therefore, education is an input in a CEO himself to produce policies because it is one of his authorities. Tax is one of the policies that the CEO should decide so the company could calculate the profit after tax, then the final estuary is the distribution of dividends for shareholders. (Aliani, 2014), has tested the relationship between education level on tax planning which is a form of tax aggressiveness, the result is that education level has a negative effect on tax planning. In contrast. (Puspita et al., 2014), showed that the educational background especially accounting and financial expertise do not influence tax avoidance as one form of tax aggressiveness.

Upper Echelons Theory also states that one of the demographic characteristics that influence a company's policies is CEO tenure. (Astutik et al., 2020), evidence the positive influence between CEO tenure toward tax aggressiveness and stated that as CEO tenure increases, he/she will be more aggressive in doing tax planning, and tax planning is one of 
the company's policies. (Duan et al., 2018), also evidence that CEO tenure has negative influence toward tax avoidance and implied that at earlier tenure CEO will receive more attention from investors and public and be more aggressive in doing tax planning to meet the investors expectation which is higher return, On the other hand (Aliani, 2014), proved that the length of time that someone held the position of CEO in the company has no significance toward tax planning, but has negative regression coefficient which in line with Duan et al 2018). (Hariyanto et al., 2018), also evidence the negative value of t-statistic but has the 0.888 significance level which described that CEO tenure has no influence toward tax aggressiveness.

Being more or less aggressive toward taxes is also dependent on the individual risk preference because each CEO is a different person which has different characteristic compare to other. Based on Upper Echelons Theory, there are two dimension of demographic characteristic that would influence the decision that an executive would take, they are observable and psychological. The courage within a person to take a risk is something psychological, and it is risk preference. Risk preference would play a role within an executive psychological characteristic in order to make a company policies which is the authority of his position. (Asri et al., 2016), evidence the influence of risk preference toward tax avoidance. (Novita, 2016), also proved that risk preference within a CEO has an influence toward tax avoidance but the founding in her research is the more risk taker an executive then the lower level of corporate tax avoidance. While (Putri et al., 2020), didn't find a significant influence of risk preference toward tax avoidance.

The resulting gap between one study compared to another is signal to examine the relationship between CEO educational background, tenure, and risk preference toward tax aggressiveness. Moreover, the result will provide consideration for the government to take the step in order accommodating the characteristics of family firm CEO toward taxes. In addition, profitability will be control variable as the evidence of it's relationship with tax aggressiveness in (Astutik et al., 2020), profitability influence toward tax aggressiveness, it also happened in (Yuwono et al., 2019), profitability has influence toward tax aggressiveness.

\section{THEORITICAL REVIEW}

Upper Echelons Theory. (Hambrick et al., 1984), presented Upper Echelons Theory that stated organizational outcomes, how a company would pick a strategy and company performance could be predicted by top-level management background characteristics. Upper echelons perspective of organizations figured that characteristics of upper echelons or top-level management especially CEO both psychological and observable would be used to respond to a given objective situation both external and internal that would be captured in company strategic choices then affect the company performance (Hambrick et al., 1984). Tax is one of the expenses that would affect profitability as one of the company performance. It is the reason why upper echelons theory could bridge top level management demographic characteristics and tax aggressiveness as one of the company policies.

Tax Aggressiveness. Tax aggressiveness is any efforts to minimize tax expense. The initial step of tax aggressiveness is tax planning, and it will lead to do a legal minimization of tax expense (tax avoidance) or in a harmful way (tax evasion) (Sari et al., 2019). Tax avoidance is done by redirecting transactions into not tax objects categories as long as allowed and not violating the tax regulations while tax evasion is done by hiding transactions 
categorized as tax objects beyond the tax regulations. (Sari et al., 2019), also stated that tax aggressiveness will bring the advantage which maximizes net profit of the company and increase the dividend to shareholders but at the same moment give the possibility to be penaltized by tax authoiries.

The connection of CEO educational background and tax aggressiveness. Education is viewed as the way to develop self-potential to accomplish self-integrity and social values to be a competent individual, creating self-moral and there is a potency within each individual that becomes gasoline to be a fire (competent) with education as the lighter (Anwar, 2015). Education gives higher opportunity in case of recruitment, higher education will make someone to have bigger chance to be recruited as CEO, the recruiter would like to see competent education as the background of their CEO candidates (Bhagat et al., 2012). This is common situation when education becomes basic filter in selecting the job seeker(in any position), the recruited would use his educational background to do the job that they have signed, so does the selected CEO. Upper echelons theory by (Hambrick et al., 1984), support that sentence with explanation that education as one of the individual demographic characteristics become input in making policy or decision within top level management. CEO as top level management will use his educational background to do the right choice in his job for keeping or creating company good performance as (Porter, 1980), mention to have a cost leadership one way or another is expense minimization, and tax is the one of the company expense. Aggressiveness toward tax planning done by top level management in order achieving cost leadership called tax aggressiveness. (Aliani, 2014), evidence the influence of CEO educational background toward tax planning. Based on that elucidation, the hypothesis that could be written is:

H1: Educational background of CEO has an effect toward tax aggressiveness.

The connection of CEO tenure and tax aggressiveness. Tenure talks about how long someone occupies in a position, in case of CEO, usually the term of time that he will have the authorization to lead the company is determined in the general meeting of shareholders and if he has the good performance he will be chosen in the next meeting. Career experience which is synergy with the time as someone work in a CEO position or top level management position called tenure has a significant influence on their action in the company (Hambrick et al., 1984). Tax expense is one of the actions that the CEO must decide and a risk decision to get more aggressive doing tax planning beyond Indonesia tax law which opens the opportunity to get sanction from tax authorities then cost the company reputation and share price. (Astutik et al., 2020), stated that the confidence within CEO is raising as the tenure increases to make a risker decision. The research concludes that as the tenure increases the tax aggressiveness would also increase. In line, (Duan et al., 2018), implied that there is a relationship between CEO tenure with tax avoidance. Based on that elucidation, the hypothesis that could be written is:

H2: Tenure of CEO has an effect toward tax aggressiveness.

The connection of CEO risk preference and tax aggressiveness. The characteristics of one individual compared to another is different, so does risk preference. Risk preference is the basic nature within individuals showed in their action toward a certain condition according to their courage to take a risk or not in deciding option that might have 
consequences. Upper echelons theory explained that there is a psychological dimension which is the cognitive base value that would influence top level management behavior in taking the action. (Hertwig et al., 2019), stated that risk preference is one of the most important in behavioral science, in economics risk preference is conceptualized with the option of returns while in psychological science it is conceptualized with the potential to get loss or harm. In line, the choice to do how much or how far tax planning would be done is the option that has been owned by the CEO. Tax aggressiveness brings the option to do the legal or illegal way on the CEO table with so many options of return and that would be one of considerations for the CEO then risk preference of CEO would play the role to the rest until the action is taken. (Asri et al., 2016), evidence that risk preference influence tax avoidance and stated that the executives who is a risk taker would be more courage in taking risk of tax avoidance. (Novita, 2016), also proved that there is a relationship between risk preference and tax avoidance. Based on that elucidation, the hypothesis that could be written is:

H3: Risk preference of CEO has an effect toward tax aggressiveness.

\section{METHODS}

The study uses data (secondary data) from many companies in several years or could be mention as panel data. The secondary data in this study which is company annual reports and financial statements are collected by documentation technique. Annual reports and financial statements are downloaded from www.idx.com. In order to find the final sample, the purposive sampling method is done by the description of family firm criteria based on (PwC, 2014). The criteria of final sample done by purposive sampling is: The company was listed in IDX for 2016 until 2019. Annual reports and financial statements of the company should contain management profiles and other information to ease in finding the variables that are needed. Controlling shareholder in the company is the founder or acquirer who has at least $25 \%$ shares and at least one of the founder's or acquirer's family member is in the $\mathrm{CEO} /$ top level management position of the company. Never experiencing the loss for 2016 until 2019. The Company's Cash Effective Tax Rate (ETR) should be in the value range of 0 until 1.

Tax aggressiveness is showed in any efforts of minimizing tax expense by doing tax planning through tax avoidance and/or tax evasios the way of n (Frank et al., 2009). Cash Effective Tax Rate is a proxy of tax aggressiveness and has been used in (Astutik et al., 2020), According to (Ross et al., 2015), the formula of CETR could be written as follows:

$$
\text { CETR }=\frac{\text { Tax Payment } \text { i period }}{\text { Profit before tax }}
$$

Education is the way for someone to light out the potential that they have inside to become a competent person. (Aliani, 2014), and (Astutik et al., 2020), proxied the educational background variable with dummy, then this study followed those prior researches using dummy by giving the value of 1 for the CEO who came from accounting, finance, or tax background with S2/Master educational level. Tenure of CEO which showed for how long a person has occupied in the CEO position of the company proxied by a 
number of years. The number of years the CEO has led the company is also used as the proxy in (Astutik et al., 2020).

Risk preference which the courage in taking a risk or not of the CEO is proxied by corporate risk, is according to (Novita, 2016), and (Hanafi et al., 2014). Corporate risk reflects the standard deviation of earning though it is more or less than what has been planned. Risk will be higher if the standard deviation of earning is higher. The formula of corporate risk could be written as follows:

$$
R I S K=\sqrt{\sum_{T-1}^{T}\left(E-1 / T \sum_{T-1}^{T} E\right)^{\wedge} 2 /(T-1)} \ldots
$$

Profitability as the control variable proxied by Return on Assets (ROA). Profitability is the ratio that could capture the performance of the company is using its assets to gain profit. (Astutik et al., 2020), who also used ROA as the control variable used the formula as follows:

$$
R O A=\frac{\text { Net Profit }}{\text { Total Assets }}
$$

The panel data regression is used to analyze the relationship between the independent variable: CEO Educational Background (EDB), CEO tenure (TEN), and CEO risk preference (RPF) toward the dependent variable which is tax aggressiveness (TAG). Earlier in examining analysis, a model estimation test is done. There is three estimation models for panel data consists of: Common Effect Model (CEM), Fixed Effect Model (FEM), and Random Effect Model (REM). Each estimation model has different nature in accommodating intercepts and slopes. The analysis of regression on panel data could be done by the result of t-statistic as the partial relationship test between each independent variable toward dependent variable and F-statistics test would be needed to exam the relationship between independent variables toward dependent variable simultaneously. The research model and equation could be drawn as follows: 


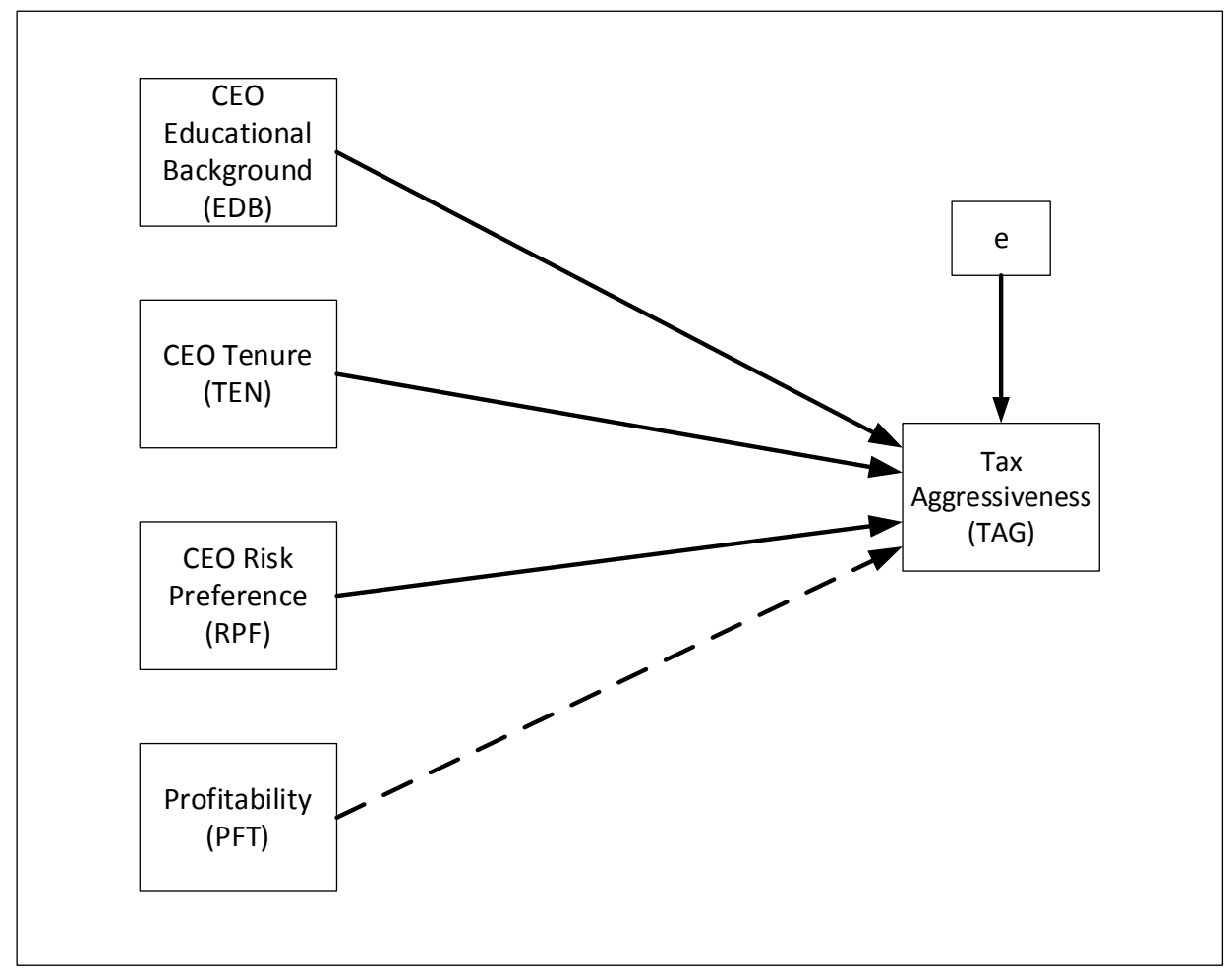

Figure 1. Research Model

Source: Data Processed

Figure 1 describe the conceptual framework of each independent variabels toward dependent variable in this study. Based on the model, the relationship of each variables could formulate in the equation as follow:

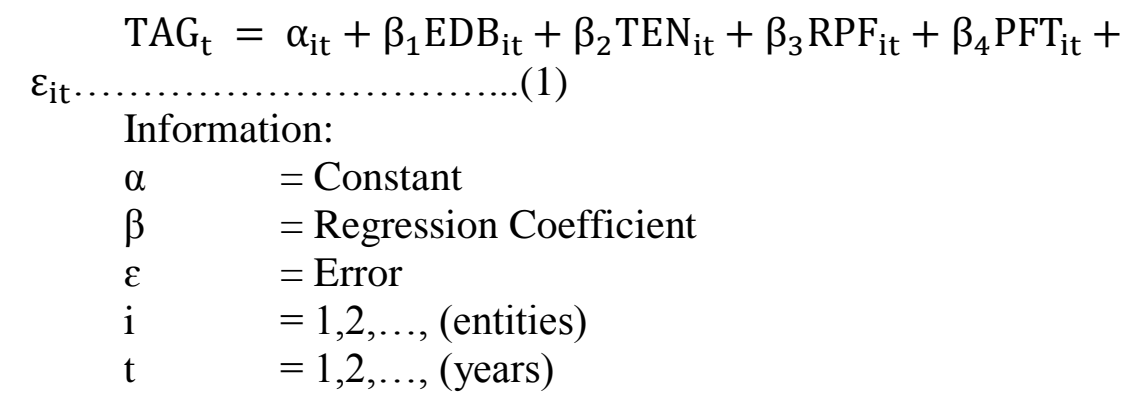

\section{RESULTS}

The Final data sample was selected using purposive sampling as shows in Table 1 there are 70 samples. In order to get the final samples, some eliminating data by some criteria called purposive sampling is done. First, there are 533 companies listed on IDX in 2016. There are 28 companies delisted from IDX during 2016 - 2019. The companies who did not categorized as family firm based on (PwC, 2014) are 392. The study needs data from family companies who experience profit during 2016 - 2019, so the family companies who experienced loss during those periods are eliminated. There is one company who did not 
give much information about CEO background to be used as the data in this study, one company who didn't publish it's financial statements which is the secondary data that is used in this study and there are two companies who had CETR value more than one, and it is not used in this study. Final data sample is used for further examination and analysis to prove the hypothesis could be accepted or not.

Table 1. Purposive Sampling Result

\begin{tabular}{lc}
\hline Companies listed on IDX 2016 period & 533 \\
Companies delisted on IDX during $2016-2019$ periods & 28 \\
Companies did not meet the family firm criteria as PwC, (2014) & 392 \\
mentioned. & 39 \\
Companies suffered losses & 1 \\
Companies have insufficient information of CEO background & 1 \\
Companies don't have published financial statements. & 2 \\
Companies have CETR value more than 1. & 70 \\
\hline Final Sample & \\
\hline
\end{tabular}

Source: The Processed Secondary Data (2021)

Table 2. Chow/Likelihood Ratio Test

\begin{tabular}{|c|c|c|c|c|}
\hline \multicolumn{5}{|c|}{$\begin{array}{l}\text { Redundant Fixed Effects Tests } \\
\text { Equation: Untitled } \\
\text { Test cross-section fixed effects }\end{array}$} \\
\hline \multicolumn{2}{|l|}{ Effects Test } & Statistic & d.f. & Prob. \\
\hline \multirow{2}{*}{\multicolumn{2}{|c|}{$\begin{array}{l}\text { Cross-section F } \\
\text { Cross-section Chi-square }\end{array}$}} & 11.705503 & $(69,206)$ & 0.0000 \\
\hline & & 446.170498 & 69 & 0.0000 \\
\hline \multicolumn{5}{|c|}{$\begin{array}{l}\text { Cross-section fixed effects test equation: } \\
\text { Dependent Variable: TAG } \\
\text { Method: Panel Least Squares } \\
\text { Sample: } 20162019 \\
\text { Periods included: } 4 \\
\text { Cross-sections included: } 70 \\
\text { Total panel (balanced) observations: } 280\end{array}$} \\
\hline Variable & Coefficient & Std. Error & t-Statistic & Prob. \\
\hline $\mathrm{C}$ & 0.210219 & 0.015598 & 13.47695 & 0.0000 \\
\hline EDB & 0.016895 & 0.015245 & 1.108264 & 0.2687 \\
\hline TEN & 0.002137 & 0.000754 & 2.834393 & 0.0049 \\
\hline $\mathrm{RPF}$ & 1.141395 & 0.314021 & 3.634769 & 0.0003 \\
\hline PFT & -0.593327 & 0.151391 & -3.919161 & 0.0001 \\
\hline Root MSE & 0.121403 & \multicolumn{2}{|l|}{ R-squared } & 0.085809 \\
\hline Mean dependent var & 0.225350 & \multicolumn{2}{|c|}{ Adjusted R-squared } & 0.072511 \\
\hline S.D. dependent var & 0.127201 & \multicolumn{2}{|c|}{ S.E. of regression } & 0.122502 \\
\hline Akaike info criterion & -1.343683 & \multicolumn{2}{|c|}{ Sum squared resid } & 4.126855 \\
\hline Schwarz criterion & -1.278776 & \multicolumn{2}{|c|}{ Log likelihood } & 193.1156 \\
\hline Hannan-Quinn criter. & -1.317648 & \multicolumn{2}{|l|}{ F-statistic } & 6.453077 \\
\hline Durbin-Watson stat & 0.406347 & \multicolumn{2}{|c|}{ Prob(F-statistic) } & 0.000056 \\
\hline
\end{tabular}

Source: The Processed 2021 
The estimation model test is done by first doing Chow/Likelihood Ratio Test. Chow/Likelihood Ratio test did define whether panel data should be estimated using CEM or FEM. If the result of probability cross section value is more than 0,05 then the proper estimation model that should be chosen is CEM, if the result is the opposite then it is proper to use FEM. As is showed in Table 2, the probability cross section value is 0,0000 suggests that FEM is proper to use. But there are two more estimation model should we test or compare with FEM, which is better through next tests.

Table 3. Hausman Test

Correlated Random Effects - Hausman Test

Equation: Untitled

Test cross-section random effects

\begin{tabular}{|c|c|c|c|c|}
\hline Test Summary & & $\begin{array}{l}\text { Chi-Sq. } \\
\text { Statistic }\end{array}$ & Chi-Sq. d.f. & Prob. \\
\hline Cross-section random & & 8.429378 & 4 & 0.0771 \\
\hline \multicolumn{5}{|c|}{ Cross-section random effects test comparisons: } \\
\hline Variable & Fixed & Random & Var(Diff.) & Prob. \\
\hline EDB & -0.118747 & -0.012363 & 0.002889 & 0.0478 \\
\hline TEN & 0.005073 & 0.002992 & 0.000009 & 0.4757 \\
\hline RPF & 0.736482 & 1.128398 & 40.465414 & 0.9509 \\
\hline PFT & -0.506160 & -0.548119 & 0.003208 & 0.4588 \\
\hline
\end{tabular}

Cross-section random effects test equation:

Dependent Variable: TAG

Method: Panel Least Squares

Date: 06/24/21 Time: 10:49

Periods included: 4

Cross-sections included: 70

Total panel (balanced) observations: 280

\begin{tabular}{crrrl}
\hline Variable & Coefficient & Std. Error & t-Statistic & Prob. \\
\hline C & 0.235022 & 0.144688 & 1.624338 & 0.1058 \\
EDB & -0.118747 & 0.059202 & -2.005792 & 0.0462 \\
TEN & 0.005073 & 0.003172 & 1.599408 & 0.1113 \\
RPF & 0.736482 & 6.381613 & 0.115407 & 0.9082 \\
PFT & -0.506160 & 0.139804 & -3.620494 & 0.0004 \\
\hline \multicolumn{6}{c}{ Effects Specification }
\end{tabular}

Cross-section fixed (dummy variables)

$\begin{array}{lrlr}\text { Root MSE } & 0.054729 & \text { R-squared } & 0.814218 \\ \text { Mean dependent var } & 0.225350 & \text { Adjusted R-squared } & 0.748383 \\ \text { S.D. dependent var } & 0.127201 & \text { S.E. of regression } & 0.063806 \\ \text { Akaike info criterion } & -2.444292 & \text { Sum squared resid } & 0.838660 \\ \text { Schwarz criterion } & -1.483669 & \text { Log likelihood } & 416.2008 \\ \text { Hannan-Quinn criter. } & -2.058984 & \text { F-statistic } & 12.36749 \\ \text { Durbin-Watson stat } & 1.837870 & \text { Prob(F-statistic) } & 0.000000\end{array}$

Source: The Processed 2021 
Next, determining estimation model between FEM and REM through Hausman Test. FEM is chosen if the result of the probability cross section value less than 0,05 , if it shows the opposite, then REM is chosen. Based on the result of Table 3, the probability cross section value is 0,071 , therefore based the hausman test, REM is chosen to be the estimation model, but we should test REM and CEM, which is better to be the estimation model based on the data of this study.

Table 4. Lagrange Multiplier Test

\begin{tabular}{|c|c|c|c|}
\hline \multicolumn{4}{|c|}{$\begin{array}{l}\text { Lagrange Multiplier Tests for Random Effects } \\
\text { Null hypotheses: No effects } \\
\text { Alternative hypotheses: Two-sided (Breusch-Pagan) and one-sided } \\
\text { (all others) alternatives }\end{array}$} \\
\hline & \multicolumn{3}{|c|}{ Test Hypothesis } \\
\hline & Cross-section & Time & Both \\
\hline Breusch-Pagan & $\begin{array}{l}214.6166 \\
(0.0000)\end{array}$ & $\begin{array}{l}0.512868 \\
(0.4739)\end{array}$ & $\begin{array}{l}215.1294 \\
(0.0000)\end{array}$ \\
\hline Honda & $\begin{array}{l}14.64980 \\
(0.0000)\end{array}$ & $\begin{array}{c}-0.716148 \\
(0.7631)\end{array}$ & $\begin{array}{l}9.852577 \\
(0.0000)\end{array}$ \\
\hline King-Wu & $\begin{array}{l}14.64980 \\
(0.0000)\end{array}$ & $\begin{array}{c}-0.716148 \\
(0.7631)\end{array}$ & $\begin{array}{l}2.289307 \\
(0.0110)\end{array}$ \\
\hline Standardized Honda & $\begin{array}{l}15.20193 \\
(0.0000)\end{array}$ & $\begin{array}{c}-0.426420 \\
(0.6651)\end{array}$ & $\begin{array}{l}4.967084 \\
(0.0000)\end{array}$ \\
\hline Standardized King-Wu & $\begin{array}{l}15.20193 \\
(0.0000)\end{array}$ & $\begin{array}{c}-0.426420 \\
(0.6651)\end{array}$ & $\begin{array}{c}-0.109541 \\
(0.5436)\end{array}$ \\
\hline Gourieroux, et al.* & -- & -- & $\begin{array}{l}214.6166 \\
(0.0000)\end{array}$ \\
\hline
\end{tabular}

Source: The Processed 2021

The final test is Lagrange Multiplier Test to examine REM and CEM. If the BreuschPagan in 'both' column shows the value higher than 0,05, CEM will be chosen, but if the value is less than 0,05 REM will be chosen as the estimation model regression. Based on Table 4 , the result is 0,0000 , so it could be stated that REM is used for estimation model regression in this study.

Table 5. Descriptive Statistics

\begin{tabular}{lccccc}
\hline & TAG & EDB & TEN & RPF & PFT \\
\hline Mean & 0.225350 & 0.392857 & 10.67143 & 0.020888 & 0.064296 \\
Median & 0.239949 & 0.000000 & 8.000 .000 & 0.014935 & 0.048737 \\
Maximum & 0.814617 & 1.000 .000 & 48.00000 & 0.217847 & 0.455579
\end{tabular}




$\begin{array}{llllll}\text { Minimum } & 0.000000 & 0.000000 & 1.000 .000 & 0.000701 & 0.000526\end{array}$

Source: The Processed 2021

Table 5 shows the descriptive statistics of samples. Tax aggressiveness is proxied by CETR which Asuttik et.al (2020), stated that lower value of CETR indicates the higher aggressiveness on tax. According to mean value of tax aggressiveness is 0,225350 could be stated that sample of this study is aggressive toward tax because maximum value of tax aggressiveness is 0,814617 , and mean value is less than median value which is 0,239949 . Educational background has mean value of 0,392857 and the maximum value is 1 . Educational background is proxied by dummy, this indicates that the average of sample has no background in finance, tax or accounting. The second independent variabel is CEO tenure has mean value 10,67143 and maximum value is 48 which indicates that average of sample has been occupied as CEO more than 10 years in family company. Last independent variable which is CEO risk preferences has mean value 0,020888 and it is above the median value and maximum value is 0,217847 so this could be stated that risk preferences of the sample is a risk taker. Profitability as control variabel has mean value of 0,064296 it is above the mediam value which is 0,048737 , it's maximum value is 0,455579 and minimum value is 0,000526 .

Table 6. Regression Result

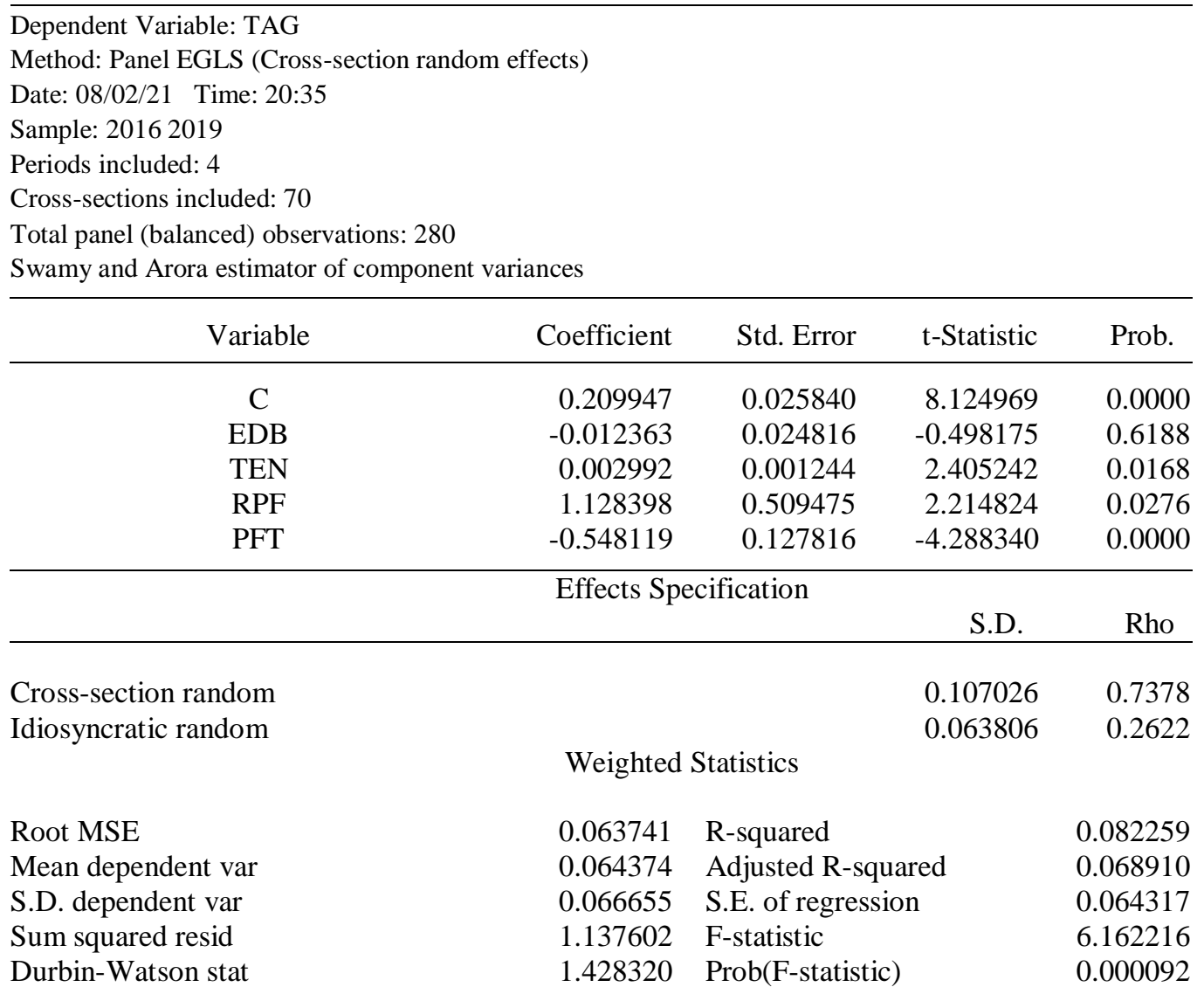

Unweighted Statistics 


\begin{tabular}{llll} 
R-squared & 0.066046 & Mean dependent var & 0.225350 \\
Sum squared resid & 4.216066 & Durbin-Watson stat & 0.385397 \\
\hline
\end{tabular}

Source: The Processed 2021

Table 6 shows the regression result of panel data. The coefficient value of regression equation is 0,209947 . CEO educational background has regression coefficient value of 0,012363 while the probability of t-statistics is 0,6188 . The regression coefficient value of CEO tenure is 0,002992 and its' probability value of t-statistics is 0,0168 . The independent variable of CEO risk preferences has regression coefficient value of 1,128398 and the probability value of t-statistics is 0,0276 . Profitability as control variable has regression coefficient value of $-0,548119$ and its' probability value of t-statistic is 0,0000 . R-squared value is 0,082259 or $8,2 \%$. The regression equation could be written as follows:

$$
\begin{aligned}
& \text { TAG }=0,209947_{i t}-0,012363 \mathrm{EDB}_{\mathrm{it}}+0,002992 \mathrm{TEN}_{\mathrm{it}}+1,128398 \mathrm{RPF}_{\mathrm{it}}- \\
& 0,548119 \mathrm{PFT}_{\mathrm{it}}+\varepsilon_{\mathrm{it}} \\
& \text { Information: } \\
& \varepsilon=\text { Error } \\
& \text { i } \quad=1,2, \ldots,(\text { entities }) \\
& \mathrm{t} \quad=1,2, \ldots,(\text { years })
\end{aligned}
$$

\section{DISCUSSION}

The value of $\mathrm{R}$-Squared is $8,25 \%$, this means that independent variables: CEO educational background, CEO tenure and CEO risk preference has influence toward dependent variable simultaneously only $8,25 \%$ out of $100 \%$. This indicates that there are still independent variables out of this study that would influence dependent variable and might be showed by increased value of R-Squared. The study of (Astutik et al., 2020), has the value of R-Squared more than $80 \%$. Their study used some variables that differ from this study as an example is gender of CEO as independent variable. Gender is also used as independent variable in (Wicaksono et al., 2021), and the value of R-squared in their study is also more than $80 \%$. Therefore, it might be right decision for the government to analyse the connection between the gender of CEO in order to get more consideration to arrange regulations about tax because it might have big influence toward tax aggressiveness of family company in Indonesia.

The connection between CEO educational background and tax aggressiveness. The study results that the educational background of CEO has negative relationship toward tax aggressiveness. According to regression coefficient value of educational background it could be stated that the CEO who has educational background in accounting, tax, or finance would be less aggressive toward tax because the value of regression coefficient value is negative, it is in line with (Astutik et al., 2020), which also has resulted in the same negative regression coefficient. The descriptive statistics shows that the most sample of this study has finance, accoungting or tax background based on the mean value which above the median. The CEO with finance, accounting or tax background would be less aggressive toward tax because they have knowledge about fiscal failures, although they are a risk-taker but their knowledge would make them less aggressive toward tax expense (Aliani, 2014). 
So, the CEO with higher education about finance, accounting or tax would be more compliance in tax (Kakunsi et al, 2017). But, this independent variable is not significant based on the probability value of t-statistic which above 0,05, it is relevant with (Puspita et al., 2014). So, the first hypothesis or H1 is rejected, CEO educational background has no effect toward tax aggressiveness. The government could give more attention toward the leader of company in Indonesia by doing seminar or etc that would increase the knowledge of each CEO about tax, so based on this study that step would minimalize the aggressiveness of company in arranging their tax expense.

The connection between CEO tenure and tax aggressiveness. CEO tenure has regression coefficient value of 0,002992 (positive value) it means that every one year someone occupied as the CEO, his aggressiveness toward tax increase as much as 0,002992. The result describes that the longer someone is occupied as the CEO, he will be more aggressive toward tax. It is because of increasing confidence within himself in taking decisions or policies toward tax in the family companies (Astutik etal., 2020). This positive value of regression coefficient value is the same as (Astutik et al., 2020). CEO tenure's probability value of t-statistics is below the significance level 0,05 . It could be stated that $\mathrm{H} 2$ is accepted, so CEO tenure has an effect toward tax aggressiveness. This result is supported by Upper Echelons Theory that stated tenure of CEO or top level management would influence them in making decisions or policies in the company that they led. Aggressiveness toward tax expense is one of the decisions that the CEO faces during his leadership. This result is not in line with (Aliani, 2014), and (Hariyanto et al., 2018). Although that the tenure of CEO proved influence toward tax aggressiveness, it is only influenced as much as 0,002992 each one year as someone is occupied as CEO. The government should anticipate toward the company that led by CEO for long years because he/she is more aggressive in tax.

The connection between CEO risk preference and tax aggressiveness. According to Table 6, CEO risk preference has the highest regression coefficient value, it indicates that the most influencing variable toward tax aggressiveness is risk preference of the CEO. CEO risk preference also has the probability value of $t$-statistics below the significance level and it means that $\mathrm{H} 3$ is accepted. CEO risk preference has an effect toward tax aggressiveness. This result is in line with (Novita, 2016) and (Hanafi et al., 2014). (Hambrick et al., 1984), figured that psychological dimensions of demographic characteristics within the CEO, influence them in making company policies. (Hertwig et al., 2019), explained that in economics, risk preference of someone has a relation with moneter value of the return. Positive value of regression coefficient means that CEO who is a risk taker in family company would like to be more aggressive toward tax expenses to gain higher profit. This has a relation with (Martinez et al., 2014) who found that family companies is more aggressive toward tax expenses. This section outlines the answers for research problems and recommendations for the next research. The government can accommodate the CEO's risk preferences by taking stricter sanctions on tax violators. Therefore, the level of consideration for daring to take risks that will be accepted if a company is proven to have violated tax regulations will tend to decrease. 


\section{CONCLUSION}

Tax is the main income for the country but its collecting is on another side with the company's objective to gain profit higher as they can. (Martinez et al., 2014), stated that family companies are more aggressive toward taxes while the survey did by (PwC, 2014), $95 \%$ of business in Indonesia is family companies. Based on tax aggressiveness mean value of descriptive statistics could be stated that family companies in Indonesia are aggressive toward taxes so the government should take a step in accommodating this nature of family companies in order to maximize state revenue from the tax sector. In accommodating the aggressiveness of family companies toward taxes, the government should know that the most important factor that influences top-level management or the CEO of family companies is the CEO risk preference. The government also should know that another factor that influences the tax aggressiveness of family companies in Indonesia is CEO tenure. The longer CEO has experienced in leading the family company, the more aggressive CEO toward taxes while the CEO educational background has no influence toward tax aggressiveness. So the government must take an action in minimizing risk-taker within the CEO such as through tax law enforcement that has been proved by (Putra et al., 2020), reinforcing taxpayer compliance.

This study has limitations such as: there are a lot of tax aggressiveness proxies, further researches could add or combine other proxies that may give a better result. And also should look for other independent variables outside this study for a better R-squared value that indicates increased influence of independent variables simultaneously toward tax aggressiveness.

\section{REFERENCES}

Aliani, K. (2014). CEO characteristics and corporate tax planning evidence from US companies. International Journal of Managerial and Financial Accounting, 6(1), 4959. https://doi.org/10.1504/IJMFA.2014.060508.

Anwar, M. (2015). Filsafat Pendidikan. Jakarta: Kencana.

Asri, I. A. T. Y., dan Suardana, K. A. (2016). Pengaruh Proporsi Komisaris Independen, Komite Audit, Preferensi Risiko Eksekutif Dan Ukuran Perusahaan Pada Penghindaran Pajak. E-Jurnal Akuntansi, 16(1), 72-100.

Astutik, D., and Venusita, L. (2020). The Influence of CEO's Demographic Characteristics on Tax Aggressiveness in Family Firm. Jurnal Akuntansi Dan Keuangan, 22(1), 1-9. https://doi.org/10.9744/jak.22.1.1-9

Bhagat, S., Bolton, B. J., and Subramanian, A. (2012). CEO Education, CEO Turnover, and Firm Performance. SSRN Electronic Journal. https://doi.org/10.2139/ssrn.1670219

Duan, T., Ding, R., Hou, W., and Zhang, J. Z. (2018). The burden of attention: CEO publicity and tax avoidance. Journal of Business Research, 87(0), 90-101. https://doi.org/10.1016/j.jbusres.2018.02.010

Frank, Mary Margaret; Lynch, Luann J.; Rego, S. O. (2009). Tax Reporting Aggressiveness and Its Relation to Aggressive Financial Reporting.

Hambrick, D. C., and Mason, P. A. (1984). Echelons : of Reflection The Its Organization as Top a. Academy of Management Review, 9(2), 193-206.

Hanafi, Umi; Harto, P. (2014). Analisis Pengaruh Kompensasi Eksekutif, Kepemilikan 
Saham Eksekutif Dan Preferensi Risiko Eksekutif Terhadap Penghindaran Pajak Perusahaan. Diponegoro Journal of Accounting, 3(2), 1162-1172.

Hariyanto, F., dan Utomo, D. C. (2018). Pengaruh Corporate Governance Dan Kompensasi Eksekutif Terhadap Agresivitas Pajak (Studi Empiris Perusahaan Jasa Sektor Keuangan yang Terdaftar di BEI Tahun 2014 - 2016). Diponegoro Journal of Accounting, 7(4), 1-14.

Hertwig, R., Wulff, D. U., and Mata, R. (2019). Three gaps and what they may mean for risk preference. Philosophical Transactions of the Royal Society of London. Series B, Biological Sciences, 374(1766), 20180140. https://doi.org/10.1098/rstb.2018.0140.

Kakunsi, E., Pangemanan, S., dan Pontoh, W. (2017). Pengaruh Gender Dan Tingkat Pendidikan Terhadap Kepatuhan Wajib Pajak Di Wilayah Kantor Pelayanan Pajak Pratama Tahuna. Going Concern: Jurnal Riset Akuntansi, 12(2), 391-400. https://doi.org/10.32400/gc.12.2.17771.2017.

Martinez, A. L., and Ramalho, G. C. (2014). Family Firms and Tax Aggressiveness in Brazil. International Business Research, 7(3), 129-136. https://doi.org/10.5539/ibr.v7n3p129.

Novita, N. (2016). Executives Characters, Gender and Tax Avoidance: A Study on Manufacturing Companies in Indonesia. 15, 92-95. https://doi.org/10.2991/gcbme16.2016.15.

Porter, M. E. (1980). Books by competitive strategy.

Price Waterhouse Cooper (PwC). (2014). Survey bisnis keluarga 2014. November 2014, (November), 1-35. Retrieved from https://www.pwc.com/id/en/publications/assets/indonesia-report-family-businesssurvey-2014.pdf.

Puspita, S. R., dan Harto, P. (2014). Pengaruh Tata Kelola Terhadap Penghindaran Pajak. Diponegoro Journal of Accounting, 3(2), 1-2. Retrieved from https://ejournal3.undip.ac.id/index.php/accounting/article/view/6172.

Putra, Edrick Purnama; Tjaraka, H. (2020). Tax Law Enforcement in Strengthening Tax Compliance Behavior of Individual Taxpayers. Jurnal Akuntansi, 24(1), 154. https://doi.org/10.24912/ja.v24i1.664.

Putri, R. O. W., dan Indriani, E. (2020). Pengaruh Kepemilikan Saham Eksekutif, Kompensasi Eksekutif dan Preferensi Risiko Eksekutif Terhadap Penghindaran Pajak. ADVANCE : Jurnal Akuntansi, 7(1), 64-75.

Ross, S. A; Westerfield, R. W.; Jordan, B. D.; Liim, J.; Tan, R. (2015). Pengantar Keuangan Perusahaan. Jakarta: Salemba Empat.

Sari, P., and Prihandini, W. (2019). Corporate Social Responsibility and Tax Aggressiveness in Perspective Legitimacy Theory. International Journal of Economics, Business and Accounting Research (IJEBAR), 3(04), 330-343. https://doi.org/10.29040/ijebar.v3i04.726.

Wicaksono, K., and Oktaviani, R. M. (2021). Effect of CEO Characteristics Toward Tax Aggressiveness : Overview of Indonesia Family Firms. Jurnal Ekonomi, XXVI(02), $179-195$.

Wicaksono, K., Meita Oktaviani, R., dan Stikubank Semarang, U. (2021). Pengaruh Karakteristik Ceo Terhadap Agresivitas Pajak Dalam Perusahaan Keluarga. Jurnal Akuntansi, 16(1), 59-73.

Yuwono; Fuad. (2019). Pengaruh Corporate Governance Dan Kompensasi Eksekutif Terhadap Agresivitas Pajak. Diponegoro Journal of Accounting, 8(3), 1-12. 